\title{
Acute sulphide toxicity in Perinereis aibuhitensis under different salinities and temperatures: $\mathrm{LC}_{50}$ and antioxidant responses
}

\author{
Haiqing Wang ${ }^{1,2}$, Guodong Wang ${ }^{3}$, Jianguang Fang ${ }^{1,4}$, Zengjie Jiang ${ }^{1,4}$, \\ Meirong Du ${ }^{1,4}$, Yaping Gao ${ }^{1,4}$, Jinghui Fang ${ }^{1,4, *}$ \\ ${ }^{1}$ Key Laboratory for Sustainable Utilization of Marine Fisheries Resources, Ministry of Agriculture \\ Yellow Sea Fisheries Research Institute, 266071 Qingdao, PR China \\ ${ }^{2}$ Norwegian University of Science and Technology, 7491 Trondheim, Norway \\ ${ }^{3}$ Marine Science and Engineering College, Qingdao Agriculture University, 266109 Qingdao, PR China \\ ${ }^{4}$ Laboratory for Marine Fisheries Science and Food Production Processes, \\ Qingdao National Laboratory for Marine Science and Technology, 266237 Qingdao, PR China
}

\begin{abstract}
Sulphide accumulates in sediment due to global aquaculture development and is very harmful to aquatic and benthic ecosystems. Perinereis aibuhitensis inhabits coastal areas and is often exposed to fairly high sulphide concentrations. The present study investigated the tolerance of $P$. aibuhitensis to sulphide to evaluate its potential application in sulphide remediation and sustainable aquaculture. We assessed the toxicity of sulphide on P. aibuhitensis in a $96 \mathrm{~h}$ acute sulphide exposure experiment under different temperature and salinity conditions. Two-way ANOVA showed that increasing salinity did not influence the $\mathrm{LC}_{50}$ of $P$. aibuhitensis exposed to sulphide. In contrast, increasing temperature significantly augmented the $\mathrm{LC}_{50}$ value $(\mathrm{p}<0.05)$. The results showed a negative relationship between mortality and temperature, and between mortality and exposure time. Subsequently, we performed 2-way ANOVA analysis of the antioxidant (superoxide dismutase [SOD], catalase [CAT] and total antioxidant capacity [T-AOC]) responses of $P$. aibuhitensis during $96 \mathrm{~h}$ exposure to sub-lethal sulphide concentrations $\left(0,80,160,320\right.$, and $\left.640 \mu \mathrm{mol} \mathrm{l}^{-1}\right)$, and a subsequent recovery period. The activation of this antioxidant defense system appeared to depend on sulphide concentration and exposure duration and their interaction. SOD, CAT, and T-AOC showed obvious differences at the beginning and end of exposure. They were steadily restored during the recovery period. The results indicated that $P$. aibuhitensis adjusts its antioxidant defense system to cope with sulphide contamination. Therefore, these indexes of $P$. aibuhitensis could be applied to environmental monitoring and bio-restoration at mudflat or intensive aquaculture areas with high sulphide concentrations.
\end{abstract}

KEY WORDS: Sulphide $\cdot$ Perinereis aibuhitensis $\cdot \mathrm{LC}_{50} \cdot$ Oxidative stress $\cdot$ Antioxidant enzyme

\section{INTRODUCTION}

Since intensive aquaculture has increased rapidly, concerns have grown about the effects of contaminants (e.g. organic enrichment, sulphide, biogenic elements) derived from aquaculture farming on the biogeochemical processes of benthic sediment, espe-

${ }^{*}$ Corresponding author: hui861@163.com cially in coastal cultivation zones (Grant et al. 1995, Holmer et al. 2005, Wilson \& Vopel 2015). Increased deposition of organic matter changes sediment biogeochemistry, which can result in oxygen depletion (Holmer et al. 2005, Metzger et al. 2014). A low oxygen concentration in the benthic environment promotes anaerobic metabolism, sulphate reduction and

(C) The authors 2017. Open Access under Creative Commons by Attribution Licence. Use, distribution and reproduction are unrestricted. Authors and original publication must be credited. 
consequently a higher concentration of dissolved sulphide in sediment pore water (Newell 2004, Sakai et al. 2013). Sulphide (the sum of $\mathrm{H}_{2} \mathrm{~S}, \mathrm{HS}^{-}$, and $\mathrm{S}^{2-}$ ) is known to be extremely toxic to most aerobic life at nanomolar to micromolar concentrations (Lamers et al. 2013). It is impossible to prevent sulphide from entering the body of aquatic organisms, and benthic organisms have evolved abilities to resist the toxicity of hydrogen sulphide (Harald \& Marianne 2015).

Sulphide has deleterious effects on aquaculture environments and on benthic macrofauna (Riedel et al. 2012, Kilminster et al. 2014). It can cause hypoxia in tissues (Hauschild \& Grieshaber 1997) and can bind at more than one enzyme site to inhibit cytochrome $c$ oxidase and many other enzymes, thereby inhibiting the aerobic metabolism and enzyme activity (Vismann 1990, Völkel \& Grieshaber 1994, Jimenez-Gutierrez et al. 2014). However, many benthic animals tolerate the toxicity of sulphide through special eco-physiological strategies (Brouwer \& Murphy 1995, Hildebrandt \& Grieshaber 2008). Early studies showed that the sulphide in pore water affects the distribution of the nereid polychaetes. Nereis virens is found in areas with low sulphide levels $(<50 \mu \mathrm{M})$, while Nereis succinea is distributed in sediments with high sulphide levels $(50-2000 \mu \mathrm{M})$ and Nereis diversicolor has a broader tolerance with regard to sulphide in porewater and is more tolerant to sulphide than N. virens (Kristensen 1988). Burrowing, macrofauna such as polychaetes enhance oxic conditions through bioturbation and bioirrigation (Goldhaber et al. 1977, Carvalho et al. 2007), which may diminish the possible negative effects of sulphide in sediment.

Aquatic organisms possess antioxidant enzymes to protect their cellular systems from oxidative damage induced by xenobiotics that can cause stresses through induction of a disbalance between the generation and elimination of reactive oxygen species (ROS) (Regoli \& Giuliani 2014, González et al. 2015). Studies have indicated that when marine organisms are exposed to oxidative stress, the activity of antioxidant enzymes will change with pollutant concentration and exposure time (Vidal-Liñán et al. 2010, Qiu et al. 2013). The fluctuations in activity of antioxidant enzymes, such as superoxide dismutase (SOD), catalase (CAT), and total antioxidant capacity (T-AOC) in polychaetes exposed to sulphide could help us to understand its physiological responses.

Polychaetes play an essential role in coastal benthic ecosystems (Leung \& Cheung 2017, Weis et al. 2017). They are important sources of food for fish and other benthic species (Fadhullah \& Syakir 2016).
They also play a role in controlling algal blooms, bioaccumulate heavy metals, and enhance oxygen and nutrient transformation at the sediment-water interface through their deposit and suspension feeding and reworking activity in coastal sediments (Baumann \& Fisher 2011, Leung \& Cheung 2017, Weis et al. 2017). Perinereis aibuhitensis (Grube) is an important commercial polychaete and is widespread in China. $P$. aibuhitensis prefers water with salinities between 24 and 32 and its respiration increases with increasing temperature within the range $10-27^{\circ} \mathrm{C}$ (Wang et al. 2004, Cai \& Yan 2014). It has been shown that $P$. aibuhitensis can be used as a remediation species co-cultured in shrimp or fish farms to convert wastes to valuable biomass (Honda \& Kikuchi 2002, Fang et al. 2014, 2016). In addition, it is an indicator for multiple-contaminant (e.g. heavy metals and petroleum hydrocarbons) accumulation and remediation (Ge et al. 2016a,b). Deng et al. (2006) found that the accumulation of sulphide in sediment was reduced when $P$. aibuhitensis was introduced into shrimp ponds.

The objectives of this study were to evaluate the tolerance of the polychaete $P$. aibuhitensis to different sulphide concentrations and its recovery ability after being removed from sulphide. We also evaluated the activity of its antioxidant systems during sulphide exposure and a subsequent recovery period. The results will be helpful for evaluating the application of polychaetes in bio-monitoring and biorestoration of sulphide-contaminated areas.

\section{MATERIALS AND METHODS}

\section{Animals and general conditions}

Perinereis aibuhitensis were collected from Dingzi Bay, a semi-enclosed bay in southeastern Shandong Province, PR China, in September 2015. Polychaetes were transported to the laboratory in wet sawdust and maintained in a recirculating system filled with filtered seawater (salinity 30, pH 7.8-8.1, temperature $18^{\circ} \mathrm{C}$ ) containing $10 \mathrm{~cm}$ of sand before the experiments. Organisms were fed with a mixture of fish fodder, algae powder, wheat bran, and diatoms. A simulated natural photoperiod (14 h light:10 h dark) was used throughout the experiment. During the day the light intensity was less than 100 lux to prevent photolysis of sulphide, except for the short period during which the samples were collected. Animals were acclimated in the recirculation tanks for $7 \mathrm{~d}$ before the study. 


\section{Acute toxicity test}

A $96 \mathrm{~h}$ assay was conducted to evaluate the toxicity of sulphide on $P$. aibuhitensis. A stock solution of $160 \mathrm{mmol} \mathrm{l}^{-1}$ sulphide (sum of $\mathrm{H}_{2} \mathrm{~S}, \mathrm{HS}^{-}$, and $\mathrm{S}^{2-}$ ) was prepared by mixing the $\mathrm{Na}_{2} \mathrm{~S} \cdot 9 \mathrm{H}_{2} \mathrm{O}$ crystals with $\mathrm{N}_{2}$ saturated distilled water. Then, the stock solution was adjusted to $\mathrm{pH} 8.0$ with $1 \mathrm{~mol} \mathrm{l}^{-1} \mathrm{HCl}$. The experimental setup was a flow-through system consisting of a stock solution tank, a filtered seawater tank, and an incubation chamber (Fig. 1), which kept both dissolved oxygen (DO) and $\mathrm{H}_{2} \mathrm{~S}$ at a constant level. One system can connect with 1-8 incubation chambers in which one grid can hold 2 polychaetes. The flow rate of the stock solution and seawater were adjusted to create different sulphide concentrations. Stock solution and seawater were mixed uniformly by a small pump before entering the incubation chamber. A stock solution tank was placed in darkness and sealed with paraffin oil to maintain the solution concentration. The stock solution was re-filled at intervals of 6-8 $\mathrm{h}$. The time for the mixed seawater going through the incubation chamber was about 10-15 min.

Intact and healthy polychaetes $(1.38 \pm 0.12 \mathrm{~g}$, mean $\pm \mathrm{SD}$ ) were selected for the experiment. Experiments were carried out by varying 3 factors: sulphide concentration, salinity, and temperature. Experimental concentrations of sulphide were $0,80,160,320,640$, 1280 , and $2560 \mathrm{\mu M} \mathrm{l}^{-1}$, and the corresponding hydrogen sulphide $\left(\mathrm{H}_{2} \mathrm{~S}\right)$ concentrations (Unisense) in the incubation chamber were $0,10.34,22.44,41.31,53.09$,
91.62, and $148.21 \mu \mathrm{M} \mathrm{l}^{-1}$, respectively. The salinities were 30,27 , and 24 , and the temperatures were 25 , 20 , and $15^{\circ} \mathrm{C}$. In total, there were 63 treatments with 4 replicates of each. Ten individuals were placed in each replicate, and a total of 2520 polychaetes were used. There were 21 systems with 4 incubation chambers for each temperature treatment at one time. The process above was conducted for one salinity at a time. The DO level was above $5.12 \mathrm{mg} \mathrm{l}^{-1}$. The salinities and temperatures were adjusted gradually by $1-2$ units per day before the $7 \mathrm{~d}$ acclimation period.

\section{Sulphide exposure and recovery experiment}

Sample collection and preparation of tissue extracts

Three hundred polychaetes were collected randomly after acclimation to laboratory temperature in the recirculating tanks. Then they were exposed to a series of sublethal sulphide concentrations $(0,80$, 160, 320, and $640 \mu \mathrm{M} \mathrm{l}^{-1}$ ) for $96 \mathrm{~h}$. These sulphide concentrations were lower than the calculated $\mathrm{LC}_{50}$ value at $15^{\circ} \mathrm{C}$. In the recovery experiments, sulphide toxicity was removed and all animals were then placed in clean seawater for $96 \mathrm{~h}$. There were 4 replicates in all treatments $(\mathrm{n}=15)$. The water temperature was maintained at $15^{\circ} \mathrm{C}$, salinity was 30 , and $\mathrm{pH}$ was 8.0. Samples were collected after $6,12,24$, 48,72 , and $96 \mathrm{~h}$ during both the sulphide exposure and sulphide recovery periods for determination of

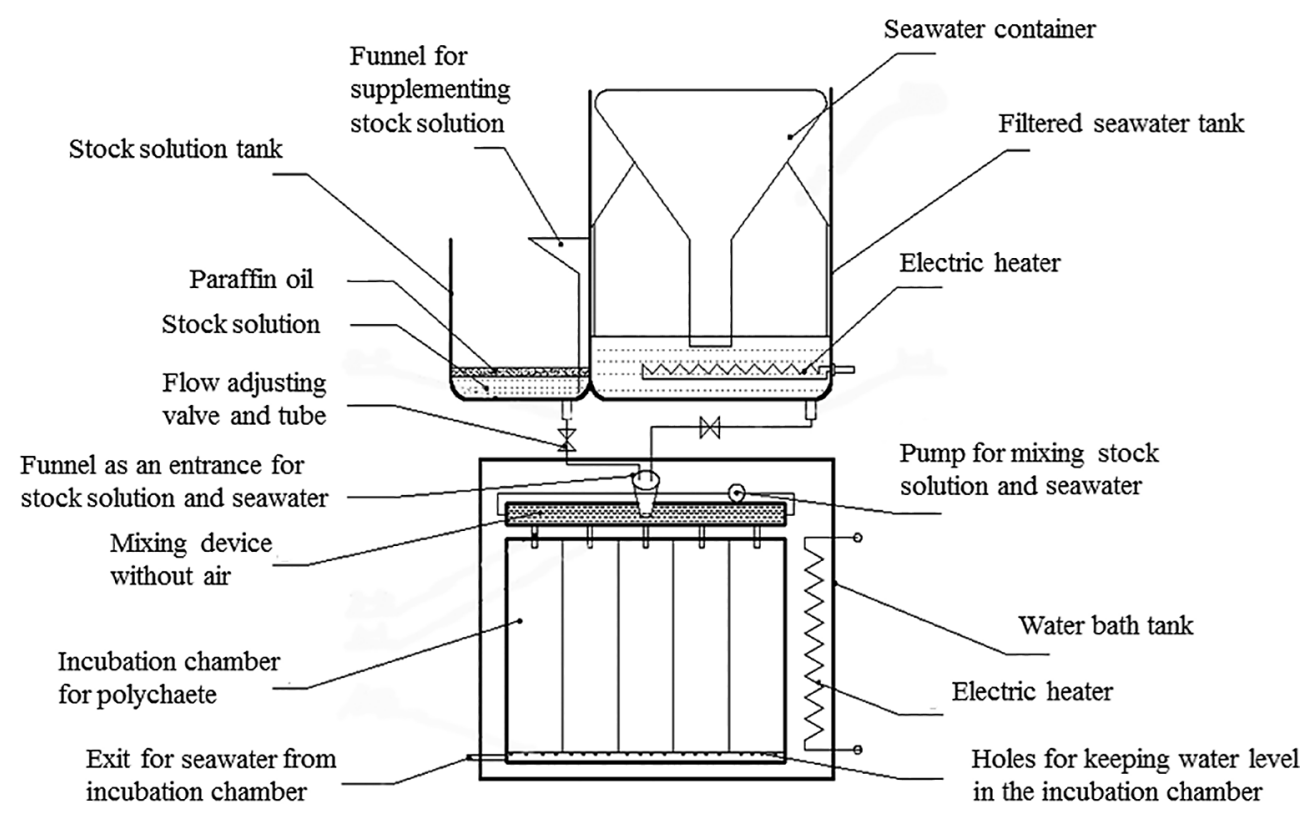

Fig. 1. The flow-through system used in this study 
enzyme activity. Polychaetes were dissected from between the head and the beginning of the tail, as there are no morphological changes in this region along its body length (Wohlgemuth et al. 2000). Tissue samples were placed in centrifuge tubes, immediately frozen in liquid nitrogen, and then stored at $-80^{\circ} \mathrm{C}$ until analysis.

Tissue samples were homogenized individually in 9 volumes (the ratio of buffer volume to tissue weight) of PBS buffer solution ( $\mathrm{pH} 7.2-7.8$ ) with multifunctional homogenizer (Precellys 24 Dual) at $4^{\circ} \mathrm{C}$. Homogenates were then centrifuged at $2016 \times g$ for 10 min at $4^{\circ} \mathrm{C}$. Supernatants for the determination of $\mathrm{SOD}, \mathrm{CAT}$, and T-AOC were tested within $12 \mathrm{~h}$. SOD, CAT, and T-AOC were analyzed using kits (Nanjing Jiancheng Bioengineering Institute) based on the Coomassie Blue protein assay.

\section{Enzyme activity test}

SOD activity was determined by the ability of this enzyme to inhibit the reduction of nitro blue tetrazolium at $37^{\circ} \mathrm{C}$ (Wu \& Tiedemann 2002). CAT decomposes hydrogen peroxide, thereby preventing its accumulation. This reaction can be ceased by ammonium molybdate, producing a yellow complex compound alongside hydrogen peroxide, which can be determined by absorbance at $405 \mathrm{~nm}$ (Sánchez-Valle et al. 2012, Tian et al. 2014). T-AOC was determined by its ability to reduce $\mathrm{Fe}^{3+}$ to $\mathrm{Fe}^{2+}$, which was measured using the absorbance at $520 \mathrm{~nm}$, where 1 unit is defined an increase in optical density (OD) of 0.01 per minute (He et al. 2013). Protein content was detected using the Coomassie Blue staining method (Brunelle \& Green 2014). The enzyme activities are expressed as U mg protein $^{-1}$.

\section{Statistical analysis}

All treatments were carried out with 4 replicates. The data are expressed as means $\pm \mathrm{SD}$. $\mathrm{LC}_{50}$ (concentration which causes $50 \%$ mortality) values of $\mathrm{H}_{2} \mathrm{~S}$ were calculated by linear interpolation. The safe concentration (SC) was calculated based on the following formula: $\mathrm{SC}=96 \times \mathrm{LC}_{50} \times 0.1$. Two-way ANOVA (main effect) was used to identify the effect of salinity and temperature on $\mathrm{LC}_{50}$ of $\mathrm{H}_{2} \mathrm{~S}$ at each sampling time. The interactions between sulphide concentration and exposure and recovery time on the enzyme activities of the polychaetes were also tested by 2way ANOVA (SPSS 13.0 for Windows). If an interaction between the 2 main factors in the 2-way ANOVA model was significant, one-way ANOVA was used to examine the effects of sulphide concentrations on the enzyme activities at a given exposure time. Homogeneity of variances was tested with a Levene test. If the homogeneity of variances was not significant, a Bonferroni test was used during multiple comparisons. Otherwise, the non-parametric Dunnett's T3 test was used. The statistical significance level is $\mathrm{p}<0.05$.

\section{RESULTS}

\section{Acute toxicity and $\mathrm{LC}_{50}$}

During the $96 \mathrm{~h}$ toxicity test period, no mortality of polychaetes was observed in the control solutions at any salinity and temperature. The $\mathrm{LC}_{50}$ and SC values of $\mathrm{H}_{2} \mathrm{~S}$ are shown in Table 1. The 2-way ANOVA (main effect) showed that there was no significant difference among the different salinity treatments (24-30) (Table 2), while the $\mathrm{LC}_{50}$ value of $\mathrm{H}_{2} \mathrm{~S}$ decreased significantly with increasing temperature

Table 1. $\mathrm{LC}_{50}$ and safe concentration (SC) of $\mathrm{H}_{2} \mathrm{~S}$ to Perinereis aibuhitensis and their $95 \%$ confidence limits under different water temperatures and salinities. $\mathrm{LC}_{50}$ : concentration that causes mortality in $50 \%$ of organisms. The SC was calculated based on the following formula: $\mathrm{SC}=96 \times \mathrm{LC}_{50} \times 0.1$

\begin{tabular}{|c|c|c|c|c|c|c|}
\hline \multirow{2}{*}{$\begin{array}{l}\text { Temp } \\
\left({ }^{\circ} \mathrm{C}\right)\end{array}$} & \multirow{2}{*}{ Salinity } & \multicolumn{5}{|c|}{$\mathrm{LC}_{50}$ of $\mathrm{H}_{2} \mathrm{~S}\left(\mu \mathrm{M} \mathrm{l}^{-1}\right)$} \\
\hline & & $24 \mathrm{~h}$ & $48 \mathrm{~h}$ & $72 \mathrm{~h}$ & $96 \mathrm{~h}$ & $\mathrm{SC}$ \\
\hline \multirow[t]{3}{*}{25} & 30 & $86.06(84.21-87.91)$ & $38.59(36.40-40.78)$ & $15.15(14.25-16.05)$ & $9.34(7.78-10.90)$ & $0.93(0.65-1.06)$ \\
\hline & 27 & $74.46(73.21-75.70)$ & $32.58(30.81-34.35)$ & $12.92(11.29-14.55)$ & $7.97(7.08-8.86)$ & $0.80(0.55-1.09)$ \\
\hline & 24 & $91.42(86.06-96.78)$ & $33.90(32.27-35.53)$ & $16.14(15.24-17.04)$ & $10.12(9.03-11.21)$ & $1.01(0.90-1.12)$ \\
\hline \multirow[t]{3}{*}{20} & 30 & $129.05(126.29-131.81)$ & 83.54 (82.40-84.68) & $65.06(62.28-67.84)$ & $54.51(48.99-60.03)$ & $5.45(4.90-6.00)$ \\
\hline & 27 & $125.88(124.48-127.28)$ & $98.42(96.84-100.00)$ & $57.94(54.27-61.61)$ & $52.39(49.13-55.65)$ & $5.24(4.91-5.56)$ \\
\hline & 24 & $123.11(120.69 \mathrm{v} 125.53)$ & $88.14(85.10-91.18)$ & $58.28(56.14-60.42)$ & $52.35(50.58-54.12)$ & $5.24(5.06-5.41)$ \\
\hline \multirow[t]{3}{*}{15} & 30 & $135.87(133.17-138.57)$ & $126.85(125.45-128.25)$ & $86.64(85.62-87.66)$ & $71.29(69.05-73.53)$ & $7.13(6.64-7.35)$ \\
\hline & 27 & $137.66(135.20-140.12)$ & $124.12(122.65-125.59)$ & $115.96(110.08-121.84)$ & $68.77(66.41-71.13)$ & $6.88(6.64-7.11)$ \\
\hline & 24 & 141.09 (139.15-143.03) & $129.32(127.69-130.95)$ & $91.58(89.74-93.42)$ & $67.19(65.11-69.27)$ & $6.72(6.51-6.93)$ \\
\hline
\end{tabular}


Table 2. Two-way ANOVA (main effect) results of $24 \mathrm{~h} \mathrm{LC}_{50}, 48 \mathrm{~h}$ $\mathrm{LC}_{50}, 72 \mathrm{~h} \mathrm{LC}_{50}$, and $96 \mathrm{~h} \mathrm{LC}_{50}$ of $\mathrm{H}_{2} \mathrm{~S}$ at different temperatures and salinities (Salt)

\begin{tabular}{|llccccc|}
\hline Source & & SS & df & MS & $F$ & $\mathrm{p}$ \\
\hline $24 \mathrm{~h} \mathrm{LC}_{50}$ & Temp & 15055.631 & 2 & 7527.816 & 352.834 & 0.000 \\
& Salt & 128.822 & 2 & 64.411 & 3.019 & 0.063 \\
$48 \mathrm{~h} \mathrm{LC}_{50}$ & Temp & 51165.682 & 2 & 25582.841 & 1194.478 & 0.000 \\
& Salt & 25.556 & 2 & 12.778 & 0.597 & 0.557 \\
$72 \mathrm{~h} \mathrm{LC}_{50}$ & Temp & 41786.487 & 2 & 20893.244 & 330.653 & 0.000 \\
& Salt & 370.220 & 2 & 185.110 & 2.930 & 0.068 \\
$96 \mathrm{~h} \mathrm{LC}_{50}$ & Temp & 23118.109 & 2 & 11559.054 & 1650.161 & 0.000 \\
& Salt & 29.562 & 2 & 14.781 & 2.110 & 0.138 \\
\hline
\end{tabular}

( $p<0.05$, Fig. 2). When the polychaetes were exposed to over $1280 \mu \mathrm{M} \mathrm{l}^{-1}$ of $\mathrm{H}_{2} \mathrm{~S}, \mathrm{LC}_{50}$ was reached reached after $72 \mathrm{~h}$ at $15^{\circ} \mathrm{C}$, after $48 \mathrm{~h}$ exposure at $20^{\circ} \mathrm{C}$ in treatments. All animals died after $72 \mathrm{~h}$ exposure in all treatments at $25^{\circ} \mathrm{C}$. Morphological abnormalities of the dead polychaetes included the phenomena of curled tail, swollen numb head, dark body color, and occasionally rupture of the epidermis. A polychaete was determined dead when it failed to respond to touch by a glass rod (Llansó 1991).

\section{Sulphide exposure and recovery experiment}

In the sulphide exposure and recovery experiment, only 2 polychaetes died and both were in the $640 \mu \mathrm{M}$ $\mathrm{l}^{-1}$ treatment.

\section{SOD activity}

The SOD activity of Perinereis aibuhitensis under sulphide stress is shown in Fig. 3. Two-way ANOVA showed that SOD activity was significantly affected

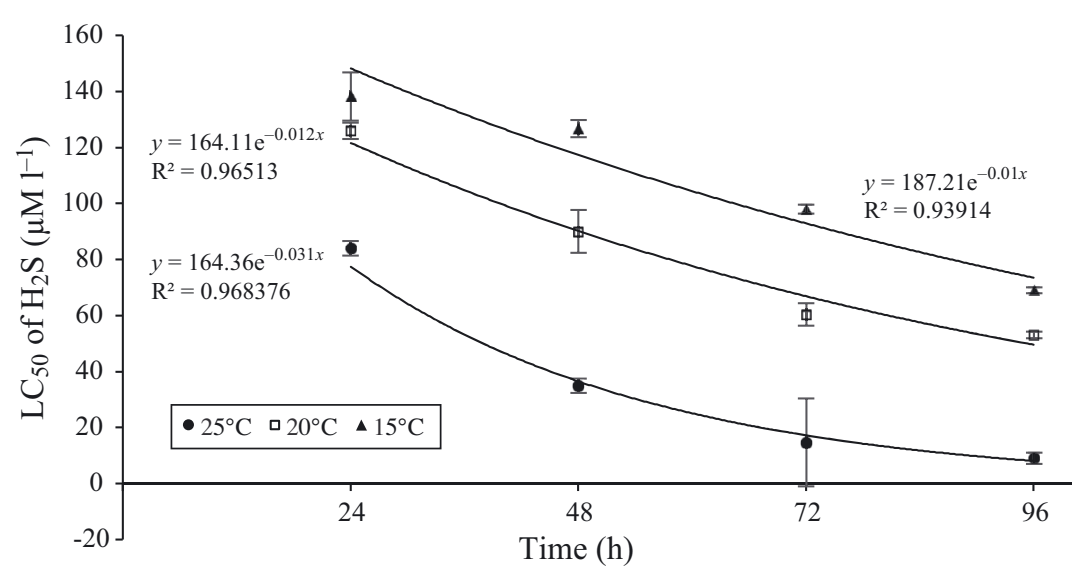

Fig. 2. Relationship between $\mathrm{LC}_{50}$ of $\mathrm{H}_{2} \mathrm{~S}$ and exposure time at 15,20 , and $25^{\circ} \mathrm{C}$ by sulphide concentration $(\mathrm{p}<0.05)$, exposure and recovery time $(\mathrm{p}<0.05)$, and their interaction $(\mathrm{p}<0.05$, Table 3$)$. Post-hoc tests showed that SOD activity at all concentrations of sulphide was lower than the control after short-term $(<6 \mathrm{~h})$ exposure. It was significantly lower in the $320 \mathrm{\mu M} \mathrm{l}^{-1}$ treatment than the control $(\mathrm{p}<0.05)$. However, the $320 \mu \mathrm{M} \mathrm{l}^{-1}$ treatment showed significantly higher SOD activity than those of the other treatments after $48 \mathrm{~h}(\mathrm{p}<0.05)$. SOD activity increased at all concentrations at $96 \mathrm{~h}$ compared with the control, which was significant at the higher concentrations (320 and $\left.640 \mu \mathrm{M} \mathrm{l}^{-1}\right)(\mathrm{p}<0.05)$. After releasing the polychaetes from sulphide for $6 \mathrm{~h}$, there was no significant difference in SOD activity among all treatments. However, it increased greatly in the $640 \mathrm{\mu M} \mathrm{l}^{-1}$ treatment compared with the control after the polychaete had been removed from sulphide for $12 \mathrm{~h}(\mathrm{p}<0.05)$, while it was lower than the control in the 80 and $320 \mu \mathrm{Ml}^{-1}$ treatments $(\mathrm{p}<0.05)$. SOD activity decreased significantly in the lower concentration $\left(80\right.$ and $\left.160 \mu \mathrm{M} \mathrm{l}^{-1}\right)$ treatments $(\mathrm{p}<0.05)$ after recovery for $48 \mathrm{~h}$. Furthermore, there were significantly low SOD activities in all treatments at $72 \mathrm{~h}$ of recovery $(\mathrm{p}<0.05)$. SOD activity remained low in the $320 \mu \mathrm{M}$ $\mathrm{l}^{-1}$ treatment at $96 \mathrm{~h}$ of recovery.

\section{CAT activity}

Two-way ANOVA showed that the CAT activity was significantly affected by sulphide concentration $(\mathrm{p}<0.05)$, exposure and recovery time $(\mathrm{p}<0.05)$, and their interaction $(\mathrm{p}<0.05$, Table 3, Fig. 4). Subsequently, post-hoc tests showed that the activity of CAT increased significantly in the lower concentration treatments (80 and $160 \mu \mathrm{M} \mathrm{l}^{-1}$ ) during the initial $6 \mathrm{~h}$ sulphide-stress period $(p<0.05)$. At $12 \mathrm{~h}$, the CAT activity increased greatly relative to the control $(\mathrm{p}<0.05)$ and was positively correlated with sulphide. The CAT activity in $P$. aibuhitensis decreased in the $80 \mu \mathrm{M} \mathrm{l}^{-1}$ treatment and increased in the higher concentration treatments (320 and $640 \mu \mathrm{M} \mathrm{l}^{-1}$ ) after exposure to sulphide for $24 \mathrm{~h}$. The 80,160 and $640 \mu \mathrm{M} \mathrm{l}^{-1}$ treatments exhibited lower CAT activity compared with the control at $48 \mathrm{~h}(\mathrm{p}<0.05)$. The CAT activity in all of the treatments was reduced relative to the control after $96 \mathrm{~h}$ of exposure $(\mathrm{p}<$ $0.05)$. The CAT activity remained low in the sulphide-stressed groups compared 


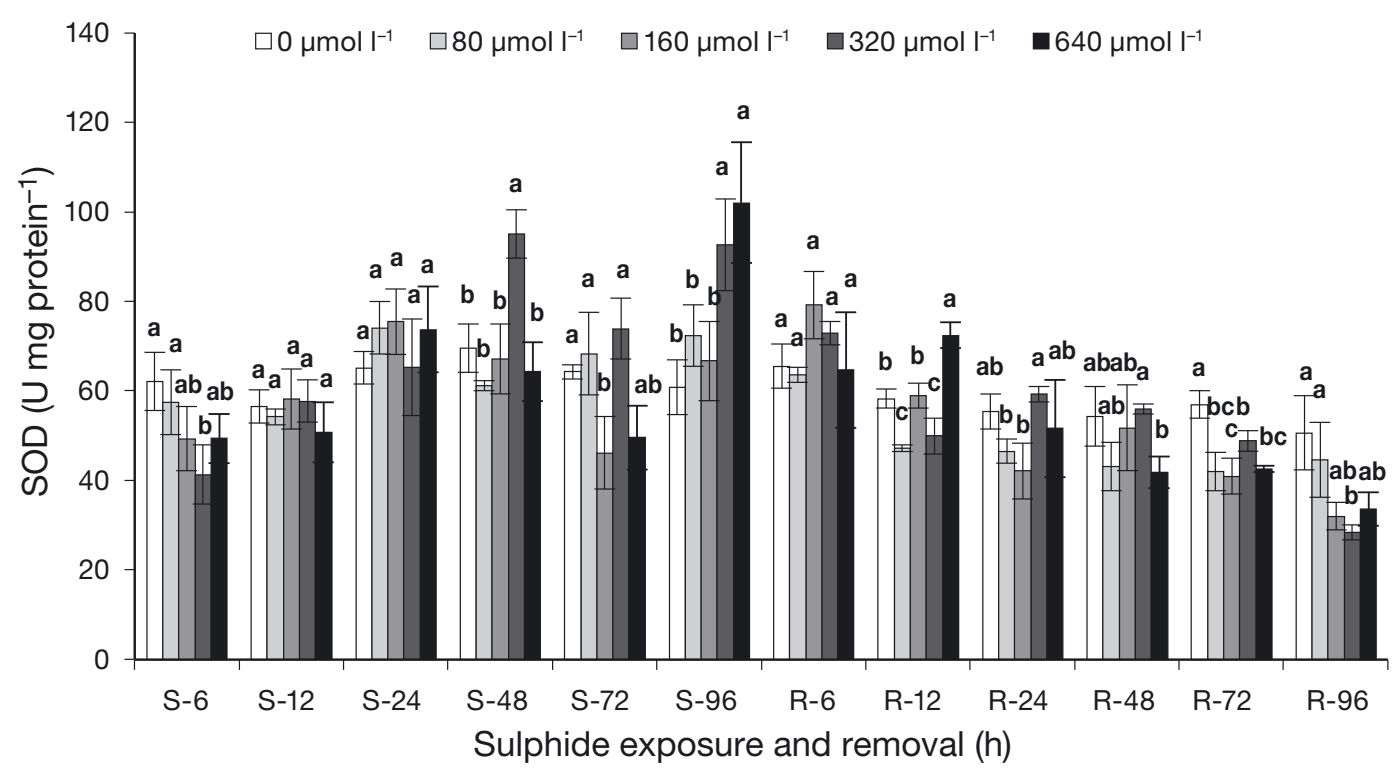

Fig. 3. Superoxide dismutase (SOD) activity in Perinereis aibuhitensis during and after the period of exposure to different concentrations of sulphide (means $\pm \mathrm{SD}$ ). $\mathrm{S}=$ exposure to sulphide; $\mathrm{R}=$ removal from sulphide. The numbers after $\mathrm{S}$ and $\mathrm{R}$ are hours of exposure/removal. Different letters denote significant differences among different sulphide concentrations at the same exposure or recovery times $(\mathrm{p}<0.05)$

with the control at the beginning of the recovery period (Fig. 4). There was significantly high CAT activity in the $160 \mu \mathrm{M} \mathrm{l}^{-1}$ treatment after $12 \mathrm{~h}$ of recovery $(\mathrm{p}<$ $0.05)$, but CAT activity of the 160 and $640 \mu \mathrm{Ml}^{-1}$ treatments decreased significantly at $72 \mathrm{~h}$ of recovery from sulphide $(p<0.05)$. Furthermore, significantly low CAT activity was observed in all treatments after $96 \mathrm{~h}$ of recovery $(\mathrm{p}<0.05)$.

\section{T-AOC}

T-AOC in $P$. aibuhitensis exposed to sulphide is shown in Fig. 5. As with SOD and CAT activity, the 2way ANOVA showed T-AOC was also significantly affected by sulphide concentration $(p<0.05)$ and ex-

Table 3. Two-way ANOVA results of enzyme (SOD, CAT, T-AOC) activities at different sulphide concentrations $\left(C_{\mathrm{S}}\right)$ and exposure/recovery time (T)

\begin{tabular}{|clcrccc|}
\hline \multirow{2}{*}{ Source } & & $\mathrm{SS}$ & $\mathrm{df}$ & $\mathrm{MS}$ & $F$ & $\mathrm{p}$ \\
\hline SOD & $C_{\mathrm{S}}$ & 1259.012 & 4 & 314.753 & 7.984 & 0.000 \\
& $\mathrm{~T}$ & 32422.882 & 11 & 2947.535 & 74.766 & 0.000 \\
& $C_{\mathrm{S}} \times \mathrm{T}$ & 16404.470 & 44 & 372.829 & 9.457 & 0.000 \\
& $C_{\mathrm{S}}$ & 70.614 & 4 & 17.654 & 19.223 & 0.000 \\
$\mathrm{CAT}$ & $\mathrm{T}$ & 277.949 & 11 & 25.268 & 27.514 & 0.000 \\
& $C_{\mathrm{S}} \times \mathrm{T}$ & 779.558 & 44 & 17.717 & 19.292 & 0.000 \\
& $C_{\mathrm{S}}$ & 14.800 & 4 & 3.700 & 4.892 & 0.001 \\
$\mathrm{~T}-\mathrm{AOC}$ & $\mathrm{T}$ & 62.786 & 11 & 5.708 & 7.547 & 0.000 \\
& $C_{\mathrm{S}} \times \mathrm{T}$ & 80.608 & 44 & 1.832 & 2.422 & 0.000 \\
\hline
\end{tabular}

posure and recovery time $(\mathrm{p}<0.05)$. Moreover, there was a significant interaction between the 2 factors $(\mathrm{p}<$ 0.05, Table 3). Subsequently, post-hoc tests showed that at the initial $6 \mathrm{~h}$ exposure to sulphide, T-AOC in all treatments increased relative to the control. During 12-48 h exposure, T-AOC under different sulphide concentrations were similar to that of the control, and average T-AOC during this period was $4.17 \pm 0.99 \mathrm{U}$ mg protein ${ }^{-1}$. After exposure to sulphide for $72 \mathrm{~h}, \mathrm{~T}$ AOC was lower in all treatments compared with the control, especially in the 80 and $160 \mu \mathrm{Ml}^{-1}$ treatments $(\mathrm{p}<0.05)$. At $96 \mathrm{~h}$ exposure, $160 \mu \mathrm{M} \mathrm{l}^{-1}$ treatments showed higher T-AOC, while $640 \mathrm{\mu M} \mathrm{l}^{-1}$ treatments showed significantly higher T-AOC than the control $(p<0.05)$. After releasing the polychaetes from sulphide for $12 \mathrm{~h}, \mathrm{~T}-\mathrm{AOC}$ was higher in the 160-640 $\mathrm{\mu M}$ $\mathrm{l}^{-1}$ treatments relative to the control $(\mathrm{p}<0.05)$. T-AOC of the $640 \mathrm{\mu M} \mathrm{l}^{-1}$ treatment still remained higher compared with the control $(p<0.05)$ at $24 \mathrm{~h}$ after removal from sulphide. T-AOC showed a similar trend to the control after $48 \mathrm{~h}$.

\section{DISCUSSION}

Sulphide is a widely distributed toxicant in aquatic habitats. Sulphide, ammonia, and nitrite are the main contaminations in intensive aquaculture and detrimentally affect cultured organisms and the environment (Bagarinao 1992). Polychaetes have a good ability to resist sulphide stress at higher levels 


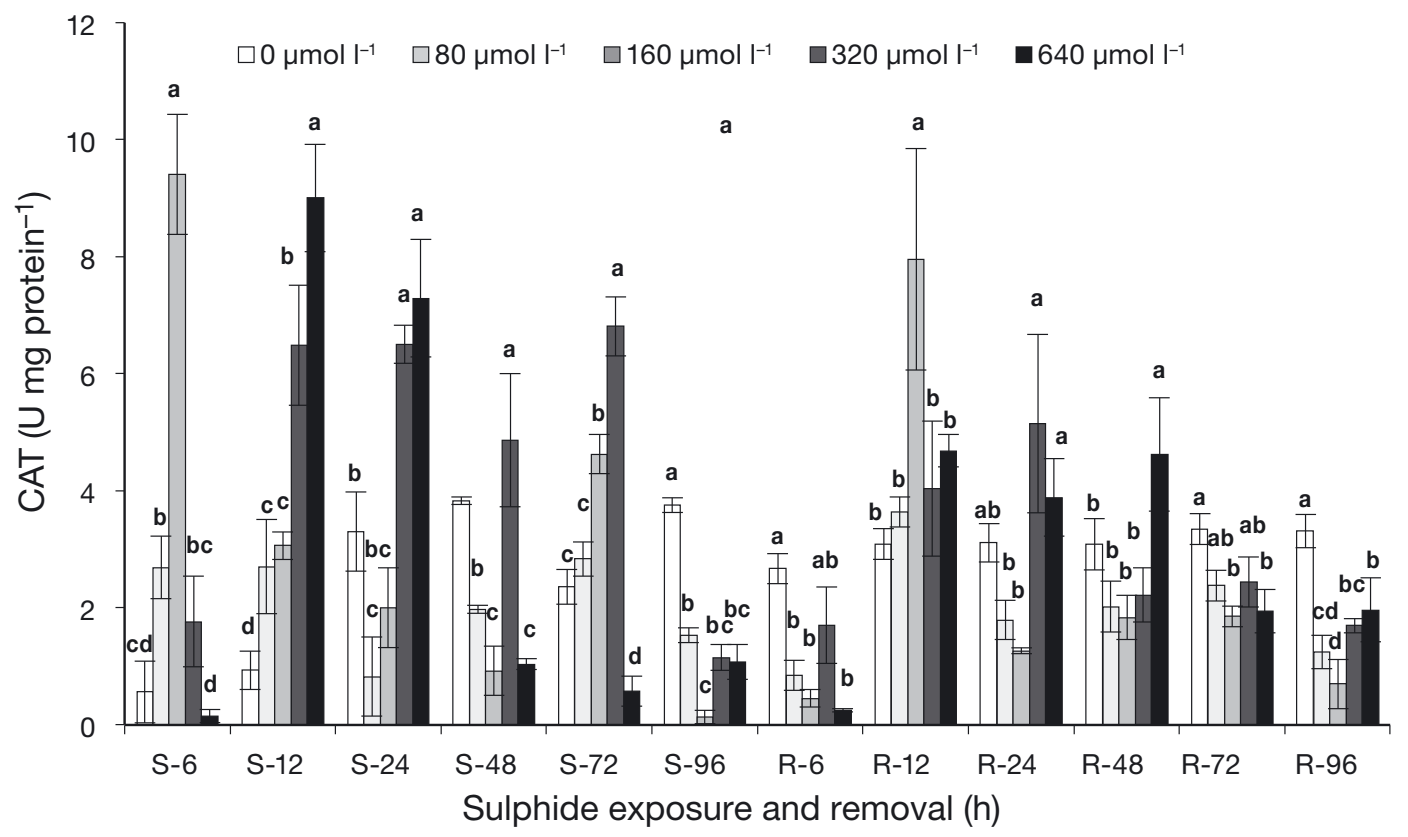

Fig. 4. Catalase (CAT) activity in Perinereis aibuhitensis during and after the period of exposure to different concentrations of sulphide (means $\pm \mathrm{SD}$ ). Abbreviations and definitions are the same as in Fig. 3

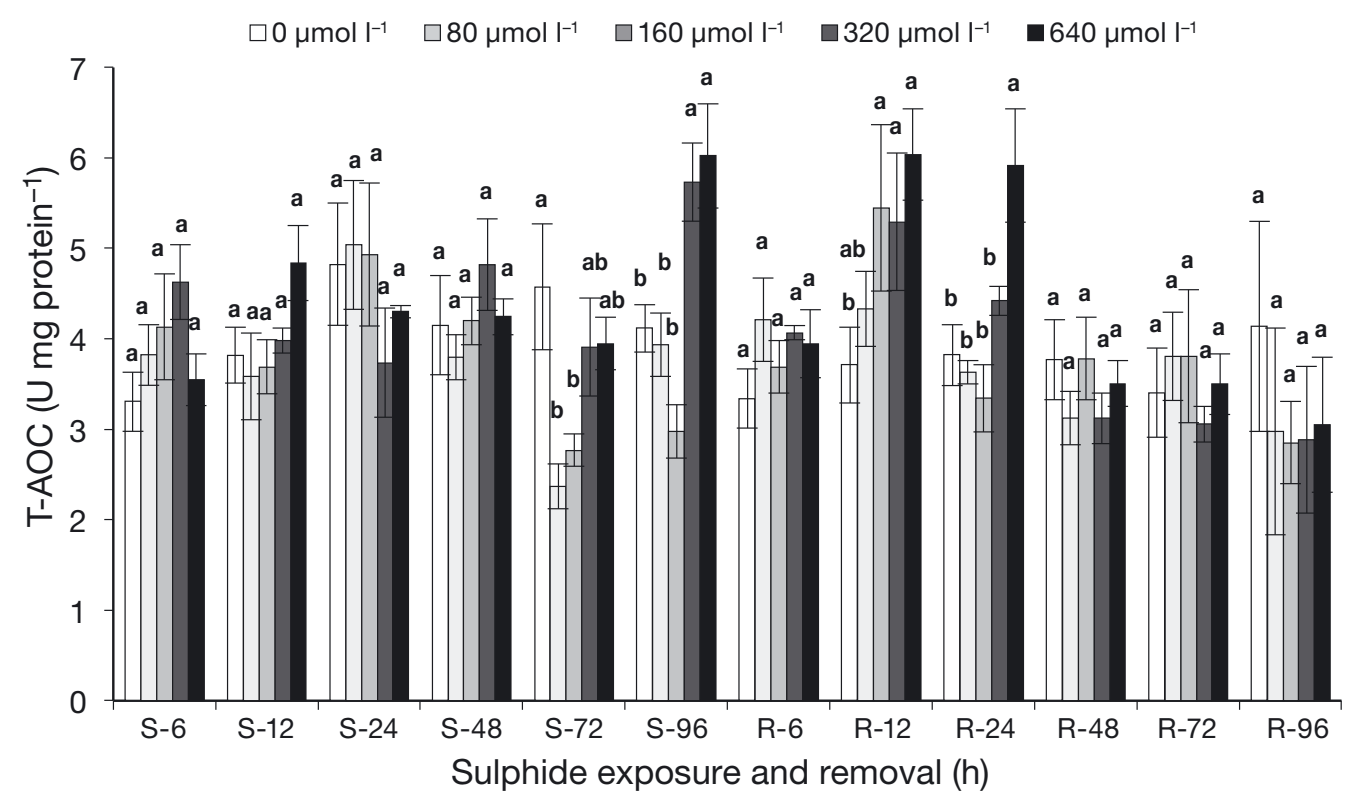

Fig. 5. Total antioxidant capacity (T-AOC) in Perinereis aibuhitensis during and after the period of exposure to different concentrations of sulphide (means \pm SD). Abbreviations and definitions are the same as in Fig. 3

than those normally found in the natural environment (Miron \& Kristensen 1993). The sulphide concentration in the living environment of the polychaete Arenicola marina is $1.7-340 \mu \mathrm{M} \mathrm{l}^{-1}$ (Völkel \& Grieshaber 1992). Hauschild \& Grieshaber (1997) found that the respiration of $A$. marina was not significantly affected during exposure to $25 \mu \mathrm{M} \mathrm{l}^{-1}$ sulphide. Miron \& Kristensen (1993) found that the sulphide concentration reached $2000 \mu \mathrm{M} \mathrm{l}^{-1}$ in the pore water of sediment in the habitat of Nereis succinea and $N$. diversicolor, but it was no more than $50 \mu \mathrm{M} \mathrm{l}^{-1}$ in the habitat of $N$. virens. This result indicates that $N$. succinea and $N$. diversicolor can tolerate higher sulphide concentrations than $N$. virens. Generally, the normal concentration of sulphide in the living environment of polychaetes is fatal for other aquatic animals, such as the crab Eriocheir sinensis, the amphipod Gammarus pseudolimnaeus, and the may- 
fly Hexagenia limbata (Wang \& Chapman 1999, Gu 2007), showing that polychaetes can endure higher sulphide concentrations than many other aquatic animals. Moreover, different polychaetes can endure different sulphide concentrations. Our study showed that the tolerance ability of Perinereis aibuhitensis for sulphide is high. The SC level (one-tenth of the $\mathrm{LC}_{50}$ at $96 \mathrm{~h}$ ) is considered to be the safe concentration of toxicant that has no detrimental effect on organisms (Sprague 1971). In the present study, we inferred that the tolerance of $P$. aibuhitensis for potentially toxic $\mathrm{H}_{2} \mathrm{~S}$ was $6.91,5.31$, and $0.86 \mu \mathrm{M} \mathrm{l}^{-1}$ at 15,20 , and $25{ }^{\circ} \mathrm{C}$, respectively. Correspondingly, the safe sulphide concentrations of $P$. aibuhitensis were $1099.48,454.61$, and $67.83 \mu \mathrm{M} \mathrm{l}^{-1}$ at 15,20 , and $25^{\circ} \mathrm{C}$, respectively.

The morphological abnormalities under sulphide toxicity differed from the phenomenon that worms detach their tails when faced with toxic metal contaminants (Tian et al. 2014). It was inferred that death was probably caused by hypoxia in tissues, because biomembranes are highly permeable to sulphide (Beerman 1924), and polychaetes produce significantly more anaerobic metabolites when exposed to sulphide, even at high $\mathrm{O}_{2}$ tensions (Hauschild \& Grieshaber 1997). Moreover, Julian et al. (1998) found that sulphide directly inhibits muscle contraction when studying the neuromuscular sensitivity of Urechis caupo to $\mathrm{H}_{2} \mathrm{~S}$.

In the acute toxicity test, the mortality rate increased with increasing temperature and $\mathrm{LC}_{50}$ showed a negative relationship with temperature and exposure time. It is known that the permeability of sulphide is high (Vismann 1990). Sulphide detoxification is highly oxygen-dependent (Hauschild \& Grieshaber 1997) and is an important way to reduce the conversion of toxic sulphide to thiosulphate (Johns et al. 1997). Since polychaete respiration increases at higher temperatures (Fadhullah \& Syakir 2016), this may result in severe hypoxia and higher mortality in polychaetes. The mortality rate of polychaetes exposed to sulphide was not affected by salinity (24-30) in the present study. Activation of antioxidant enzymes (SOD, CAT, T-AOC) in marine organisms is an important mechanism to resist various types of oxidative stress, including sulphide stress (Wang \& Chapman 1999, Vidal-Liñán et al. 2010, Qiu et al. 2013). Xu et al. (2014) found that sulphide significantly affects several enzyme activities (SOD, CAT, lysozyme (LSZ), and malondialdehyde (MDA)) of Charybdis japonica, which can be used as indicators of the immune state under sulphide contamination. SOD can catalyze the decrease of reac- tive $\mathrm{O}_{2} \cdot{ }^{-}$by transferring it to $\mathrm{H}_{2} \mathrm{O}_{2}$, which is also an important ROS. Furthermore, $\mathrm{H}_{2} \mathrm{O}_{2}$ can subsequently be detoxified by CAT. T-AOC is another antioxidant enzyme that can eliminate ROS to prevent lipid peroxidation and decompose peroxide (Xu \& Pan 2013).

It has been proposed that sulphide alters antioxidant activities by inhibiting functional enzymes (Sun et al. 2014). Our study showed that SOD activity decreased during $72 \mathrm{~h}$ sulphide exposure, but increased at $96 \mathrm{~h}$ exposure. After removal from sulphide for $12 \mathrm{~h}$, SOD activity of most treatments remained at a relatively low level. It was interesting that CAT also showed lower activity after $72 \mathrm{~h}$ of recovery. Previous studies have shown that the CAT activity of Urechis unicinctus recovers within $24 \mathrm{~h}$ after removal from sulphide exposure when it is exposed to 50 and $150 \mu \mathrm{M} \mathrm{l}^{-1}$ of sulphide for $48 \mathrm{~h}$ (Wang 2006). Völkel \& Grieshaber (1994) found that the influx of sulphide into the coelomic fluid of $A$. marina can be oxidized sufficiently under normoxia when sulphide concentrations are lower than $330 \mu \mathrm{M}$ $1^{-1}$. Otherwise, the sulphide concentration would be $5 \mu \mathrm{M} \mathrm{l}^{-1}$ in the coelomic fluid when external sulphide concentrations exceed that level. In this study, the results showed that a high sulphide concentration and long sulphide exposure required a longer time to eliminate ROS by increasing SOD and CAT activity. Moreover, when polychaetes were exposed to sulphide concentrations below $320 \mu \mathrm{M} \mathrm{l}^{-1}$, they were able recover within $24 \mathrm{~h}$ after removal from sulphide, otherwise, it took longer.

Following oxidative damage of lipids, proteins, and other molecules, ROS-induced stress can be eliminated by cellular antioxidant enzymes including CAT, SOD, and the glutathione (GSH) system (Duval et al. 2002). In the present study, we found that CAT activity was more sensitive to low concentrations of sulphide in the initial $6 \mathrm{~h}$ of exposure; however, no significant changes were observed in the higher concentration treatments (320 and $640 \mu \mathrm{M} \mathrm{l}^{-1}$ ). A similar result was also found when $P$. aibuhitensis was exposed to $\mathrm{Pb}^{2+}$ (Tian et al. 2014). Previous studies have suggested that CAT activity increases when living organisms suffer toxic oxidative stress (Nusetti et al. 2005, Tian et al. 2014). In our study, increased CAT activity was found at $12 \mathrm{~h}$ of exposure, which possibly counterbalanced sulphide-induced ROS production. Furthermore, CAT activity decreased while SOD activity increased at $96 \mathrm{~h}$ sulphide exposure. Therefore, we inferred that SOD neutralized ROS instead of CAT at this time. Nusetti et al. (2005) also found that the existence of other enzymatic and nonenzymatic antioxidants played a function instead of 
GSH activity, which could be influenced by glutathione reductase (GR) activity. CAT activity in all treatments was lower than that in the control during the initial $6 \mathrm{~h}$ of the recovery period, which seemed to be an extension of those at $96 \mathrm{~h}$ exposure. Then the CAT activity increased after $12 \mathrm{~h}$ of recovery. Moreover, the lower-concentration treatments (80 and $160 \mu \mathrm{M}$ $\mathrm{l}^{-1}$ ) maintained relatively low CAT activities during the $24-96 \mathrm{~h}$ recovery period, while the higherconcentration treatments, especially the $640 \mathrm{\mu M} \mathrm{l}^{-1}$ treatment, presented lower CAT activities until $48 \mathrm{~h}$ recovery. Thereby, we inferred that polychaetes require more time to recover from higher concentrations of sulphide stress. The results were consistent with our observations that the vitality of polychaetes, especially in the higher-concentration treatments (320 and $640 \mu \mathrm{M} \mathrm{l}^{-1}$ ), decreased after $48 \mathrm{~h}$ of exposure to sulphide and increased after $24 \mathrm{~h}$ of removal from sulphide.

T-AOC is a comprehensive reflection of the enzymatic and non-enzymatic antioxidant system (Zhou et al. 2014). In our study, T-AOC in $P$. aibuhitensis showed an increasing trend at $6 \mathrm{~h}$ exposure. Then it showed no difference from the control during 12-72 $\mathrm{h}$ exposure, and began to increase in the higher-concentration treatments at $96 \mathrm{~h}$ sulphide exposure. T-AOC was at a higher level than the control at $12 \mathrm{~h}$ removal from the sulphide. Thus, we inferred that T-AOC eliminates ROS at the beginning of exposure to sulphide and returns to a steady level after $24 \mathrm{~h}$ of recovery.

Sies (2007) proposed that the antioxidant enzyme system maintains a steady state of metabolites and functional integrity, which is organized into 3 principal levels of protection: prevention, interception, and repair. In our study, vitality of polychaetes was reduced as exposure time and sulphide concentration increased, which was more obvious after $48 \mathrm{~h}$ exposure in the higher sulphide concentration treatments (>320 $\mathrm{mmol} \mathrm{l}^{-1}$ ). Considering enzyme activity and vitality of polychaetes, enzyme activities are possibly responsible for the restoration of oxidative balance, because vitality is restored after $24 \mathrm{~h}$ of recovery. It is clear that $P$. aibuhitensis has a strong selfdetoxification system to cope with sulphide toxicity.

The increasing demand for remediation of sulphide contamination caused by intensive coastal aquaculture has led to increased interest in the ability of burrowing polychaetes to increase oxygen in sediment and thus reduce sulphide (Grieshaber \& Völkel 1998). Sulphide concentration in the habitat of $P$. aibuhitensis may be lower than the concentrations found in the present study. $\mathrm{S}^{2-}$ can combine with metal ions, such as $\mathrm{Pb}^{2+}, \mathrm{Cu}^{2+}, \mathrm{Cd}^{2+}$, and $\mathrm{Zn}^{2+}$ in the form of metal-sulphide complexes that are more oxidized and more labile. Metal-sulphide complexes are considerably less bioavailable than metal ion contaminants; thus, these meta-sulphide complexes are more toxic (Edwards et al. 2013, Simpson \& Spadaro 2016). Moreover, Joyner-Matos et al. (2010) found when worms Glycera dibranchiata were exposed in vivo to $0-10 \mathrm{mmol} \mathrm{l}^{-1}$ sulphide for $24 \mathrm{~h}$, oxidative damage to RNA and DNA in the body wall tissue occurred and coelomocytes were increased, which showed sulphide could be an environmental mutagen. Further research is needed to better understand how polychaetes detoxify sulphide, including ecophysiological studies on sulphide detoxification and metabolic pathways of polychaete in sulphidic habitat environments.

Acknowledgements. This study was supported by the National Natural Science Foundation of China (31302193, 41676147), the Primary Research and Development Plan of Shandong Province (2016GSF115027), the Special Scientific Research Funds for Central Non-profit Institutes, Yellow Sea Fisheries Research Institutes (20603022015017) and the earmarked fund for Modern Agro-industry Technology Research System (CARS-48). The authors are grateful to Qionglin Chen, Min Li, and Weiwei Jiang for all their help.

\section{LITERATURE CITED}

Bagarinao T (1992) Sulfide as an environmental factor and toxicant: tolerance and adaptations in aquatic organisms. Aquat Toxicol 24:21-62

Baumann Z, Fisher NS (2011) Modeling metal bioaccumulation in a deposit-feeding polychaete from labile sediment fractions and from pore water. Sci Total Environ 409: 2607-2615

* Beerman H (1924) Some physiological actions of hydrogen sulphide. J Exp Zool 41:33-43

Brouwer H, Murphy T (1995) Volatile sulfides and their toxicity in freshwater sediments. Environ Toxicol Chem 14: 203-208

Brunelle JL, Green R (2014) Coomassie blue staining. Methods Enzymol 541:161-167

Cai DY, Yan XZ (2014) Effects of salinity on oxygen consumption rate and ammonia-N excretion rate of Perinereis aibuhitensis. Mark Sci 38:54-59 (in Chinese with English abstract)

* Carvalho S, Barata M, Gaspar MB, Pousão-Ferreira P, da Fonseca LC (2007) Enrichment of aquaculture earthen ponds with Hediste diversicolor: consequences for benthic dynamics and natural productivity. Aquaculture 262: $227-236$

Deng JS, Ma S, Niu HX, Tian XL, Su YP (2006) Effects of introduction of Perinereis aibuhitensis Grube on the sediment quality of shrimp ponds. Periodical Ocean Univ China 2006:99-104

* Duval C, Augé N, Frisach L, Salvayre R, Nègre-Salvayre A (2002) Mitochondrial oxidative stress is modulated by 
oleic acid via an epidermal growth factor receptordependent activation of glutathione peroxidise. Biochem J 367:889-894

Edwards CD, Beatty JC, Loiselle JBR, Vlassov KA, Lefebvre DD (2013) Aerobic transformation of cadmium through metal sulfide biosynthesis in photosynthetic microorganisms. BMC Microbiol 13:161

Fadhullah W, Syakir MI (2016) Polychaetes as ecosystem engineers: agents of sustainable technologies. In: Ahmad MI, Ismail M, Riffat S (eds) Renewable energy and sustainable technologies for building and environmental applications. Springer International Publishing, Puchong, p 137-150

Fang $\mathrm{JH}$, Zhang JH, Wu WG, Mao YZ, Jiang ZJ, Fang JG (2014) Carbon and nitrogen budget and environmental optimization in an integrated cage culture model of Japanese flounder with Perinereis aibuhitensis. J Fish Sci China 21:390-397 (in Chinese with English abstract)

Fang JH, Zhang JH, Jiang ZJ, Du MR and others (2016) Environmental remediation potential of Perinereis aibuhitensis (Polychaeta) based on the effects of temperature and feed types on its carbon and nitrogen budgets. Mar Biol Res 12:583-594

Ge CZ, Chai YC, Wang HQ, Kan MM, Sun XD, Yang L (2016a) Reponses of Perinereis aibuhitensis metabolism to multiple-contamination: its utilization analysis for monitoring or restoration. Zhongguo Nongxue Tongbao 43:74-77 (in Chinese with English abstract)

Ge CZ, Liu YS, Chai YC, Li YM, Wang HQ, Kan MM (2016b) Uncertain responses of SOD activity of rag-worm (Perinereis aibuhitensis) to multiple-contamination. Fish Mod 43:7-12 (in Chinese with English abstract)

Goldhaber MB, Aller RC, Cochran JK, Rosenfeld JK, Martens CS, Berner RA (1977) Sulfate reduction, diffusion, and bioturbation in Long Island Sound sediments; report of the FOAM Group. Am J Sci 277:193-237

* González PM, Malanga G, Puntarulo S (2015) Cellular oxidant/antioxidant network: update on the environmental effects over marine organisms. Open Mar Biol J 9:1-13

* Grant J, Hatcher A, Scott DB, Pocklington P, Schafer CT, Winters GV (1995) A multidisciplinary approach to evaluating impacts of shellfish aquaculture on benthic communities. Estuaries 18:124-144

Grieshaber MK, Völkel S (1998) Animal adaptations for tolerance and exploitation of poisonous sulfide. Annu Rev Physiol 60:33-53

Gu SZ (2007) Studies on the effect of sulfide on adult Chinese mitten-handed crab, Eriocheir sinensis female. MA thesis, East China Normal University, Shanghai (in Chinese with English abstract)

Harald HS, Marianne H (2015) Sulfide intrusion and detoxification in the seagrass Zostera marina. PLOS ONE 10: $\mathrm{e} 0129136$

Hauschild K, Grieshaber MK (1997) Oxygen consumption and sulfide detoxification in the lugworm Arenicola marina (L.) at different ambient oxygen partial pressures and sulfide concentrations. J Comp Physiol B 167:378-388

'He XJ, Li R, Huang GM, Hwang H, Jiang XL (2013) Influence of marine oligosaccharides on the response of various biological systems to UV irradiation. J Funct Foods 5: 858-868

Hildebrandt TM, Grieshaber MK (2008) Redox regulation of mitochondrial sulfide oxidation in the lugworm, Arenicola marina. J Exp Biol 211:2617-2623

Holmer M, Wildish D, Hargrave B (2005) Organic enrich- ment from marine finfish aquaculture and effects on sediment biogeochemical processes. In: Hargrave BT (ed) Environmental effects of marine finfish aquaculture. Springer, Berlin, p 181-206

*Honda H, Kikuchi K (2002) Nitrogen budget of polychaete Perinereis nuntia vallata fed on the feces of Japanese flounder. Fish Sci 68:1304-1308

Jimenez-Gutierrez LR, Uribe-Carvajal S, Sanchez-Paz A, Chimeo C, Muhlia-Almazan A (2014) The cytochrome $C$ oxidase and its mitochondrial function in the whiteleg shrimp Litopenaeus vannamei during hypoxia. J Bioenerg Biomembr 46:189-196

Johns AR, Taylor AC, Atkinson RJA, Grieshaber MK (1997) Sulphide metabolism in thalassinidean crustacea. J Mar Biol Assoc UK 77:127-144

Joyner-Matos J, Predmore BL, Stein JR, Leeuwenburgh C, Julian D (2010) Hydrogen sulfide induces oxidative damage to RNA and DNA in a sulfide-tolerant marine invertebrate. Physiol Biochem Zool 83:356-365

Julian D, Dalia WE, Arp AJ (1998) Neuromuscular sensitivity to hydrogen sulfide in the marine invertebrate Urechis caupo. J Exp Biol 201:1393-1403

Kilminster K, Forbes V, Holmer M (2014) Development of a 'sediment-stress' functional-level indicator for the seagrass Halophila ovalis. Ecol Indic 36:280-289

Kristensen E (1988) Factors influencing the distribution of nereid polychaetes in Danish coastal waters. Ophelia 29: $127-140$

Lamers LP, Govers LL, Janssen IC, Welle JJ and others (2013) Sulfide as a soil phytotoxin - a review. Front Plant Sci 4:268

* Leung JY, Cheung NK (2017) Feeding behaviour of a serpulid polychaete: turning a nuisance species into a natural resource to counter algal blooms? Mar Pollut Bull $115: 376-382$

พLlansó RJ (1991) Tolerance of low dissolved oxygen and hydrogen sulfide by the polychaete Streblospio benedicti (Webster). J Exp Mar Biol Ecol 153:165-178

Metzger E, Langlet D, Viollier E, Koron N and others (2014) Artificially induced migration of redox layers in a coastal sediment from the Northern Adriatic. Biogeosciences 11: 2211-2224

*Miron G, Kristensen E (1993) Behavioral response of three nereid polychaetes to injection of sulfide inside burrows. Mar Ecol Prog Ser 101:147-155

Newell RIE (2004) Ecosystem influences of natural and cultivated populations of suspension-feeding bivalve molluscs: a review. J Shellfish Res 23:51-62

Nusetti O, Zapata-Vívenes E, Esclapés MM, Rojas A (2005) Antioxidant enzymes and tissue regeneration in Eurythoe complanata (Polychaeta: Amphinomidae) exposed to used vehicle crankcase oil. Arch Environ Contam Toxicol 48:509-514

Qiu JB, Ma FF, Fan H, Li AF (2013) Effects of feeding Alexandrium tamarense, a paralytic shellfish toxin producer, on antioxidant enzymes in scallops (Patinopecten yessoensis) and mussels (Mytilus galloprovincialis). Aquaculture 396-399:76-81

Regoli F, Giuliani ME (2014) Oxidative pathways of chemical toxicity and oxidative stress biomarkers in marine organisms. Mar Environ Res 93:106-117

Riedel B, Zuschin M, Stachowitsch M (2012) Tolerance of benthic macrofauna to hypoxia and anoxia in shallow coastal seas: a realistic scenario. Mar Ecol Prog Ser 458: $39-52$ 
Sakai S, Nakaya M, Sampei Y, Dettman DL, Takayasu K (2013) Hydrogen sulfide and organic carbon at the sediment-water interface in coastal brackish Lake Nakaumi, SW Japan. Environ Earth Sci 68:1999-2006

Sánchez-Valle V, Chavez-Tapia NC, Uribe M, MéndezSánchez N (2012) Role of oxidative stress and molecular changes in liver fibrosis: a review. Curr Med Chem 19: 4850-4860

Sies H (2007) Total antioxidant capacity: appraisal of a concept. J Nutr 137:1493-1495

Simpson SL, Spadaro DA (2016) Bioavailability and chronic toxicity of metal sulfide minerals to benthic marine invertebrates: implications for deep sea exploration, mining and tailings disposal. Environ Sci Technol 50:4061-4070

Sprague JB (1971) Measurement of pollutant toxicity to fish: III. Sublethal effects and 'safe' concentrations. Water Res 5:245-266

Sun Z, Wang L, Zhang T, Zhou Z and others (2014) The immunomodulation of inducible hydrogen sulfide in Pacific oyster Crassostrea gigas. Dev Comp Immunol 46: 530-536

* Tian Y, Liu H, Wang Q, Zhou J, Tang X (2014) Acute and chronic toxic effects of $\mathrm{Pb}^{2+}$ on polychaete Perinereis aibuhitensis: morphological changes and responses of the antioxidant system. J Environ Sci 26:1681-1688

Vidal-Liñán L, Bellas J, Campillo JA, Beiras R (2010) Integrated use of antioxidant enzymes in mussels, Mytilus galloprovincialis, for monitoring pollution in highly productive coastal areas of Galicia (NW Spain). Chemosphere 78:265-272

Vismann B (1990) Sulfide detoxification and tolerance in Nereis (Hediste) diversicolor and Nereis (Neanthes) virens (Annelida: Polychaeta). Mar Ecol Prog Ser 59:229-238

Völkel S, Grieshaber MK (1992) Mechanisms of sulfide tolerance in the peanut worm Sipunculus nudus (Sipunculida) and in the lugworm Arenicola marina (Polychaeta). J Comp Physiol B 162:469-477

Völkel S, Grieshaber MK (1994) Oxygen dependent sulfide detoxification in the lugworm Arenicola marina. Mar Biol 118:137-147

Editorial responsibility: Alistair Poore, Sydney, New South Wales, Australia
Wang SF (2006) The oxidative detoxification and metabolic adaptation of Urechis unicinctus to sulfide. MSc thesis, Ocean University China, Qingdao (in Chinese with English abstract)

Wang F, Chapman PM (1999) Biological implications of sulfide in sediment-a review focusing on sediment toxicity. Environ Toxicol Chem 18:2526-2532

Wang L, Chen AH, Zhao X, Wang L, Zhang JC, Zhou YB (2004) Effects of the temperature and body weight on respiration and excretion in Perinereis aibuhitensis Grube. J Dalian Fish Univ 19:176-181 (in Chinese with English abstract)

Weis WA, Soares CHL, de Quadros DPC, Scheneider M, Pagliosa PR (2017) Urbanization effects on different biological organization levels of an estuarine polychaete tolerant to pollution. Ecol Indic 73:698-707

*Wilson PS, Vopel K (2015) Assessing the sulfide footprint of mussel farms with sediment profile imagery: a New Zealand trial. PLOS ONE 10:e0129894

*Wohlgemuth SE, Taylor AC, Grieshaber MK (2000) Ventilatory and metabolic responses to hypoxia and sulphide in the lugworm Arenicola marina (L.). J Exp Biol 203: 3177-3188

Wu YX, Tiedemann AV (2002) Impact of fungicides on active oxygen species and antioxidant enzymes in spring barley (Hordeum vulgare L) exposed to ozone. Environ Pollut 116:37-47

Xu WJ, Pan LQ (2013) Enhancement of immune response and antioxidant status of Litopenaeus vannamei juvenile in biofloc-based culture tanks manipulating high $\mathrm{C} / \mathrm{N}$ ratio of feed input. Aquaculture 412-413:117-124

* Xu XH, Zhang YQ, Yan BL, Xu JT, Tang Y, Du DD (2014) Immunological and histological responses to sulfide in the crab Charybdis japonica. Aquat Toxicol 150: $144-150$

K Zhou C, Ge X, Lin H, Niu J (2014) Effect of dietary carbohydrate on non-specific immune response, hepatic antioxidative abilities and disease resistance of juvenile golden pompano (Trachinotus ovatus). Fish Shellfish Immunol 41:183-190

Submitted: September 26, 2016; Accepted: March 16, 2017 Proofs received from author(s): May 16, 2017 